\title{
CDON Gene
}

National Cancer Institute

\section{Source}

National Cancer Institute. CDON Gene. NCI Thesaurus. Code C24290.

This gene plays a role in myoblast differentiation. 